\title{
ANALISIS KUALITAS PELAYANAN DAN KEPUASAN PELANGGAN DI UPTD LABORATORIUM LINGKUNGAN DINAS LINGKUNGAN HIDUP PROVINSI JAMBI TAHUN 2020
}

\author{
Analysis of Service Quality and Customer Satisfaction at UPTD Environmental \\ Laboratory of the Environmental Service of Jambi Province in 2020
}

\author{
Larasati Hazairin $^{1}$, Novi Berliana ${ }^{1}$, H. Parman ${ }^{1}$ \\ ${ }^{1}$ Program Studi Ilmu Kesehatan Masyarakat STIKES Harapan Ibu Jambi
}

\begin{abstract}
Abstrak
Peningkatan mutu pelayanan publik adalah titik penting sebagai ujung akhir dari keseluruhan reformasi administrasi pemerintah. Tujuan dari penelitian ini untuk mengetahui gambaran analisis kualitas pelayanan dan kepuasan pelanggan di UPTD Laboratorium Lingkungan Dinas Lingkungan Hidup Provinsi Jambi Tahun 2020. Penelitian ini bersifat Deskriptif Kuantitatif dengan metode IPA (Importance Performance Analysis). Penelitian ini dilakukan di UPTD Laboratorium Lingkungan Dinas Lingkungan Hidup Provinsi Jambi pada bulan Agustus sampai denga September 2020. Sampel penelitian adalah pelanggan di UPTD Laboratorium Lingkungan Dinas Lingkungan Hidup Provinsi Jambi sebanyak 90 orang. Teknik pengambilan sampel menggunakan teknik accidental teknik. Instrumen yang digunakan adalah kuesioner. Teknik pengumpulan data dengan pemberian kuesioner melalui wawancara. Data dianalsis menggunakan Diagram Kartesius. Hasil penelitian menunjukkan bahwa rata-rata gambaran tingkat kepuasan pelanggan berdasarkan lima dimensi mutu pelayanan adalah sebesar $86,57 \%$. Hasil penelitian dari dimensi kehandalan adalah 79,20\%, dimensi ketanggapan adalah 84,20\%, dimensi keyakinan adalah 89,23\%, dimensi empati adalah 88,08\% dan dimensi berwujud adalah 92,13\%. Diharapkan UPTD Laboratorium Lingkungan Dinas Lingkungan Hidup Provinsi Jambi untuk meningkatkan kualitas pelayanan dari lima dimensi kualitas pelayanan yaitu kehandalan, ketanggapan, keyakinan, empati dan berwujud, agar dapat meningkatkan kepuasan pelanggan.
\end{abstract}

\section{Kata Kunci :Kehandalan, Ketanggapan, Keyakinan, Empati dan Berwujud}

\begin{abstract}
Improving the quality of public services is an important point as the final result of the overall government administration reform. The purpose of this study was to describe the analysis of service quality and customer satisfaction at UPTD Environmental Laboratory of the Environmental Service of Jambi Province in 2020. This research is a descriptive quantitative with IPA method (Importance Performance Analysis). The research was conducted at UPTD Environmental Laboratory of the Environmental Service of Jambi Province from August to September 2020.The sample of this research was 90 customers at UPTD Environmental Laboratory of the Environmental Service of Jambi Province. The sampling technique used by this research was accidental technique. The instrument was a questionnaire. The technique of collecting data was by giving questionnaires through interviews. Data were analyzed using a Cartesian diagram. The results showed that the average description of the level of customer satisfaction based on the five dimensions of service quality was $86.57 \%$. The results of the reliability dimension were $79.20 \%$, the responsiveness dimension was $84.20 \%$, the belief dimension was $89.23 \%$, the empathy dimension was $88.08 \%$ and the tangible dimension was $92.13 \%$. It is expected that UPTD Environmental Laboratory of the Environmental Service of Jambi Province will improve service quality in order to increase customer satisfaction through the five dimensions, i.e. reliability, responsiveness, belief, empathy and tangibility.

Key words: reliability, responsiveness, belief, empathy and tangibility
\end{abstract}

Korespondensi : Larasati Hazairin

Email : larasati310196@gmail.com 


\section{PENDAHULUAN}

Membangun

kepercayaan masyarakat terhadap pelayanan publik yang dilakukan penyelenggara pelayanan publik merupakan kegiatan yang harus dilakukan seiring dengan harapan dan tutunan seluruh warga negera dan penduduk tentang peningkatan pelayanan publik. Untuk menghadapi kondisi dan perubahan yang cepat pada aktivitas pembangunan tersebut khususnya pelayanan publik perlu disikapi secara bijak melalui langkah kegiatan yang terus menerus dan berkesinambungan untuk membangun kepercayaan masyarakat guna mewujudkan pembangunan nasional. ${ }^{1}$

Peningkatan mutu pelayanan publik adalah titik penting sebagai ujung akhir dari keseluruhan reformasi administrasi pemerintah, hal ini beralasan oleh karena mutu pelayanan yang diselenggarakan oleh sektor publik sampai saat ini masih sangat memprihatinkan, dimana sampai saat ini masih banyak terdapat kritikan dan saran terhadap mutu pelayanan publik, karena itu kinerja pelayanan publik menjadi titik strategis dimana kepercayaan masyarakat secara luas kepada pemerintah dipertaruhkan. Oleh karena itu peningkatan mutu pelayanan publik diperlukan untuk membangun kepercayaan masyarakat terhadap aparatur sebagai penyedia pelayanan publik dalam rangka peningkatan kesejahteraan masyarakat dengan menjadikan keluhan masyarakat sebagai masukan untuk melakukan perbaikan pelayanan publik. ${ }^{1}$

Penyelesaian masalah lingkungan dan peningkatan kualitas pelayanan publik dalam mengurangi pencemaran lingkungan merupakan tanggung jawab pemerintah. Pemerintah Republik Indonesia membentuk suatu badan yang berwenang mengurusi pencemaran lingkungan yaitu Kementerian Lingkungan Hidup. Kementerian Lingkungan Hidup mempunyai tugas mewujudkan pembangunan Indonesia berdasarkan pembangunan berkelanjutan dengan penekanan pada ekonomi hijau (green economy) untuk menahan laju kemerosotan daya tampung, daya dukung, dan kelangkaan sumber daya alam, serta mengatasi bencana lingkungan. ${ }^{1}$

Dinas Lingkungan Hidup Kota Jambi sebagai salah satu lembaga teknis daerah mempunyai beberapa fungsi, salah satunya adalah penyelenggaraan urusan pemerintahan dan pelayanan Laboratorium di bidang lingkungan hidup. Dalam meningkatkan fungsi pelayanan Laboratorium Dinas Lingkungan Hidup harus memperhatihan kualitas pelayanan yang diberikaan agar mencapai kepuasan masyarakat.

UPTD Laboratorium Lingkungan Dinas Lingkungan Hidup Provinsi Jambi, telah berdiri sejak tahun 2003 mengacu pada manajemen ISO/IEC 21930;2017, melayani fasilitas pengujian kualitas sampel air, udara dan tanah. Kurang lebih telah 13 tahun berdiri, UPTD Laboratorium Lingkungan Dinas Lingkungan Hidup Provinsi Jambi melayani permintaan pengujian sampel dari berbagai intasi perusahaan dan perorangan yang berada di Provinsi Jambi, dalam rangka pemantauan kualitas air, udara dan tanah agar tidak mencemari lingkungan. Lingkungan yang tercemar dapat mempengaruhi kesehatan baik untuk pekerja maupun masyarakat sekitar.

Dalam upaya melayani pelanggan, UPTD Laboratorium Lingkungan Dinas Lingkungan Hidup Provinsi Jambi memiliki alur dari mulai pengantaran sampel uji hingga hasil uji yang diterima yaitu berupa Lembar Hasil Uji (LHU) yang disahkan oleh Kepala UPTD Laboratorium Lingkungan Dinas Lingkungan Hidup Provinsi Jambi. Selain memiliki alur, UPTD Laboratorium Lingkungan Dinas Lingkungan Hidup Provinsi Jambi juga memiliki batas waktu (deadline) sejak awal pemberian sampel uji sampai dengan mengeluarkan hasil. Batas waktu tersebut berkisar dari 7-21 hari kerja, tetapi kadang kala batas waktu tersebut melewati batas yang telah di 
tentukan sehingga menimbulkan keluhan dari pelanggan yang dapat menyebabkan penurunan kunjungan pelanggan di UPTD Laboratorium Lingkungan Dinas Lingkungan Hidup Provinsi Jambi.

Pada 2011 terdapat lima kriteria penentu kualitas pelayanan yaitu kehandalan yaitu kemampuan petugas dalam memberikan pelayanan, ketanggapan memberikan petugas dalam melayani pelanggan, keyakinan yaitu berupa kemampuan dan keteralampilan petugas dalam memberi pelayanan, empati atau perhatian pribadi petugas dalam memberikan pelayanan dan berwujud yaitu bukti langsung misalnya fasilitas seperti ruang tunggu, kerapian dan kebersihan tata ruang serta kerapian dan kebersihan petugas yang memberi pelayanan. ${ }^{3}$

Beberapa hasil penelitian menunjukan data tentang tingkat kepuasan pasien di beberapa negara. Hasil penelitian tingkat kepuasan pasien menurut Ndambukti tahun 2013 di Kenya 40,4\%. ${ }^{4}$ Kepuasan pasien di Bakjtapu India menurut Twayana 34\%.5 Sedangkan di Indonesia menunjukan angka kepuasan pasien $42,8 \%{ }^{6}$

$\begin{array}{ll} & \text { Hasil penelitian Handayani (2016) } \\ \text { yang menganalisis membandingkan } \\ \text { harapan dan pengalaman yang }\end{array}$
menggambarkan tingkat kepuasan pasien terhadap pelayanan kesehatan dalam aspek berwujud $72,76 \%$, kehandalan $72,09 \%$, empati $72,89 \%$, bertanggap $72,88 \%$ dan keyakinan $72,22 \%$. Tingkat kepuasan secara keseluruhan $72,58 \%$ dikategorikan puas. $^{7}$

Menurut Kotler (2002) menyatakan bahwa salah satu indikator kepuasan pelanggan adalah kunjungan pelanggan semakin menurun. Hal tersebut menunjukkan bahwa, jika pelayanan yang diberikan telah sesuai dengan harapan pelanggan maka pelanggan akan terus memilih untuk terus menggunakan jasa pelayanan tersebut, namun jika harapan pelanggan tidak sesuai dengan kenyataan makan pelanggan akan memilih menggukanan jasa pelayanan yang lain. ${ }^{3}$
Berdasarkan survei awal yang dilakukan peneliti pada 10 orang pelanggan 5 diantaranya mengeluhkan keterlambatan hasil uji yang diterima, 2 orang terkadang merasa petugas berbelitbelit jika pelanggan ingin meminta hasil via online. Maka dari itu, penulis tertarik meneliti "Analisis Kualitas Pelayanan dan Kepuasan Pelanggan Di UPTD Laboratorium Lingkungan Dinas Lingkungan Hidup Provinsi Jambi Tahun 2020".

\section{METODE}

Pada penelitian ini peneliti mengambil semua variabel yang mempengaruhi kepuasan pelanggan, peneliti ingin menganalisis kualitas pelayanan dan kepuasan pelanggan di UPTD Laboratorium Lingkungan Dinas Lingkungan Hidup Provinsi Jambi. Yang menjadi variabel independen dalam penelitian ini adalah kehandalan, ketanggapan, keyakinan, empati dan wujud dalam memberikan pelayanan di UPTD Laboratorium Lingkungan Dinas Lingkungan Hidup Provinsi Jambi. Sedangkan yang menjadi variabel dependent yaitu kepuasan pelanggan yang menerima pelayanan di UPTD Laboratorium Lingkungan Dinas Lingkungan Hidup Provinsi Jambi. Penelitian ini bersifat Deskriptif Kuantitatif dengan metode IPA (Importance Performance Analysis) yang bertujuan untuk mengukur hubungan antara persepsi konsumen dan prioritas peningkatan kualitas jasa yang dikenal pula sebagai kuadran analisis di UPTD Laboratorium Lingkungan Dinas Lingkungan Hidup Provinsi Jambi. Populasi dalam penelitian ini yaitu seluruh pelanggan yang mendapat pelayanan di UPTD Laboratorium Lingkungan Dinas Lngkungan Hidup Provinsi Jambi pada tahun 2019 yaitu sebanyak 1506 pelanggan. Dari hasil perhitungan, didapatkan hasil 90 Responden dengan menggunakan teknik accidental teknik. Sedangkan sampel di yang diambil adalah 
seluruh pelanggan yang berkunjung pernah berkunjung lebih dari satu kali. dengan kriteria sudah berkunjung atau

\section{HASIL PENELITIAN}

Tabel 1

Distribusi Kepuasan Responden Berdasarkan Dimensi Kualitas Pelayanan di UPTD Laboratorium Lingkungan Dinas Lingkungan Hidup Provinsi Jambi

\section{Tahun 2020}

\begin{tabular}{|r|l|c|c|c|}
\hline \multicolumn{1}{|c|}{ No } & \multicolumn{1}{|c|}{ Dimensi } & Harapan & Kenyataan & $\begin{array}{c}\text { Tingkat Kepuasan } \\
(\mathbf{\%})\end{array}$ \\
\hline 1 & Kehandalan & 1684 & 1334 & 79,20 \\
\hline 2 & Ketanggapan & 1266 & 1066 & 84,20 \\
\hline 3 & Keyakinan & 1225 & 1079 & 89,23 \\
\hline 4 & Empati & 1652 & 1474 & 88,08 \\
\hline 5 & Berwujud & 1614 & 1487 & 92,13 \\
\hline \multicolumn{2}{|r|}{ Jumlah } & 7441 & 6440 & 86,57 \\
\hline
\end{tabular}

Pada tabel diatas menunjukkan bahwa rata-rata tingkat kepuasan pelanggan di UPTD Laboratorium Lingkungan Dinas Lingkungan Hidup Provinsi jambi adalah $86,57 \%$. Berdasarkan 5 (lima) dimensi mutu pelayanan, persentase tingkat kepuasan terendah terdapat pada dimensi kehandalan yaitu sebesar $79,21 \%$ dan persentase tingkat kepuasan tertinggi pada dimensi berwujud yaitu sebesar $92,13 \%$.

Tabel 2

Nilai Sumbu Kenyatan (X) dan Sumbu Harapan (Y) Diagram Kartesius

\begin{tabular}{|c|c|c|c|}
\hline No & Pertanyaan & $\begin{array}{c}\text { Rata-Rata } \\
\text { Harapan (Y) }\end{array}$ & $\begin{array}{c}\text { Rata-Rata } \\
\text { Kenyataan }(\mathbf{X})\end{array}$ \\
\hline 1 & $\begin{array}{l}\text { Prosedur penerimaan sampel uji yang cepat dan } \\
\text { tepat }\end{array}$ & 4,72 & 3,96 \\
\hline 2 & $\begin{array}{l}\text { Pelayanan pemeriksaan(analisa) sampel uji yang } \\
\text { cepat dan tepat }\end{array}$ & 4,64 & 3,63 \\
\hline 3 & $\begin{array}{l}\text { Jadwal pelayanan pemberian hasil uji yang telah } \\
\text { selesai sesuai dengan waktu yang telah di } \\
\text { tentukan }\end{array}$ & 4,67 & 3.6 \\
\hline 4 & Prosedur pelayanan tidak berbelit-belit & 4,66 & 3.62 \\
\hline 5 & $\begin{array}{l}\text { Kemampuan petugas labor untuk dapat } \\
\text { menyelesaikan hasil uji dengan cepat tanggap }\end{array}$ & 4,72 & 4,00 \\
\hline 6 & $\begin{array}{l}\text { Petugas memberikan informasi yang jelas dan } \\
\text { mudah di mengerti }\end{array}$ & 4,65 & 3,93 \\
\hline 7 & $\begin{array}{l}\text { Pelayanan yang cepat pada saat pelanggan } \\
\text { membutuhkan }\end{array}$ & 4,68 & 3,91 \\
\hline 8 & $\begin{array}{l}\text { Pegetahuan dan keterampilan petugas dalam } \\
\text { menetapkan hasil uji }\end{array}$ & 4,64 & 4,10 \\
\hline 9 & $\begin{array}{l}\text { Keterampilan petugas labor dan analis dalam } \\
\text { bekerja }\end{array}$ & 4,58 & 4,05 \\
\hline 10 & Pelayanan yang sopan dan ramah & 4,56 & 4,07 \\
\hline 11 & Jaminan keamanan pelayanan dan kepercayaan & 4,55 & 4,14 \\
\hline
\end{tabular}




\begin{tabular}{|c|l|c|c|}
\hline & terhadap pelayanan & & \\
\hline 12 & $\begin{array}{l}\text { Petugas memberikan informasi pelayanan secara } \\
\text { cepat dan tepat kepada setiap pelanggan }\end{array}$ & 4,57 & 4,07 \\
\hline 13 & $\begin{array}{l}\text { Perhatian terhadap keperluan pelanggan } \\
14\end{array}$ & $\begin{array}{l}\text { Pelayanan kepada setiap pelanggan tanpa } \\
\text { memandang status sosial dan lain-lain. }\end{array}$ & 4,52 \\
\hline 15 & Kebersihan, kerapiam dan kenyamanan ruangan & 4,51 & 3,96 \\
\hline 16 & Penataan interior dan eksterior ruangan & 4,41 & 3,94 \\
\hline 17 & $\begin{array}{l}\text { Kelengkapan, kesiapan dan kebersihan alat-alat } \\
\text { yang di pakai }\end{array}$ & 4,46 & 4,17 \\
\hline 18 & Kerapian dan kebersihan penampilan petugas & 4,53 & 4,05 \\
\hline & Jumlah & 82.6 & 7,17 \\
\hline & Rata-Rata Y (sebagai sumbu Y) & 4,59 & \\
\hline & Rata-Rata X (sebagai sumbu X) & & 3,97 \\
\hline
\end{tabular}

Pada Tabel 2 diatas telah diperoleh bahwa nilai sumbu $X$ (kenyataan) adalah 3,97 dan sumbu Y (harapan) 4,59. Nilai pada sumbu kenyataan (X) dan sumbu harapan (Y) ini yang digunakan didalam pembuatan diagram kartesius sehingga dapat diketahui prioritas masalah atau prioritas perbaikan di UPTD Laboratorium
Lingkungan Dinas Lingkungan Hidup Provinsi Jambi Tahun 2020. Setelah dilakukan pengolahan data dan penginputan nilai simbu (X) dan sumbu $(\mathrm{Y})$, diagram kartesius dalam penelitian ini adalah sebagai berikut :

\section{Bagan 1}

\section{Diagram Kartesius}

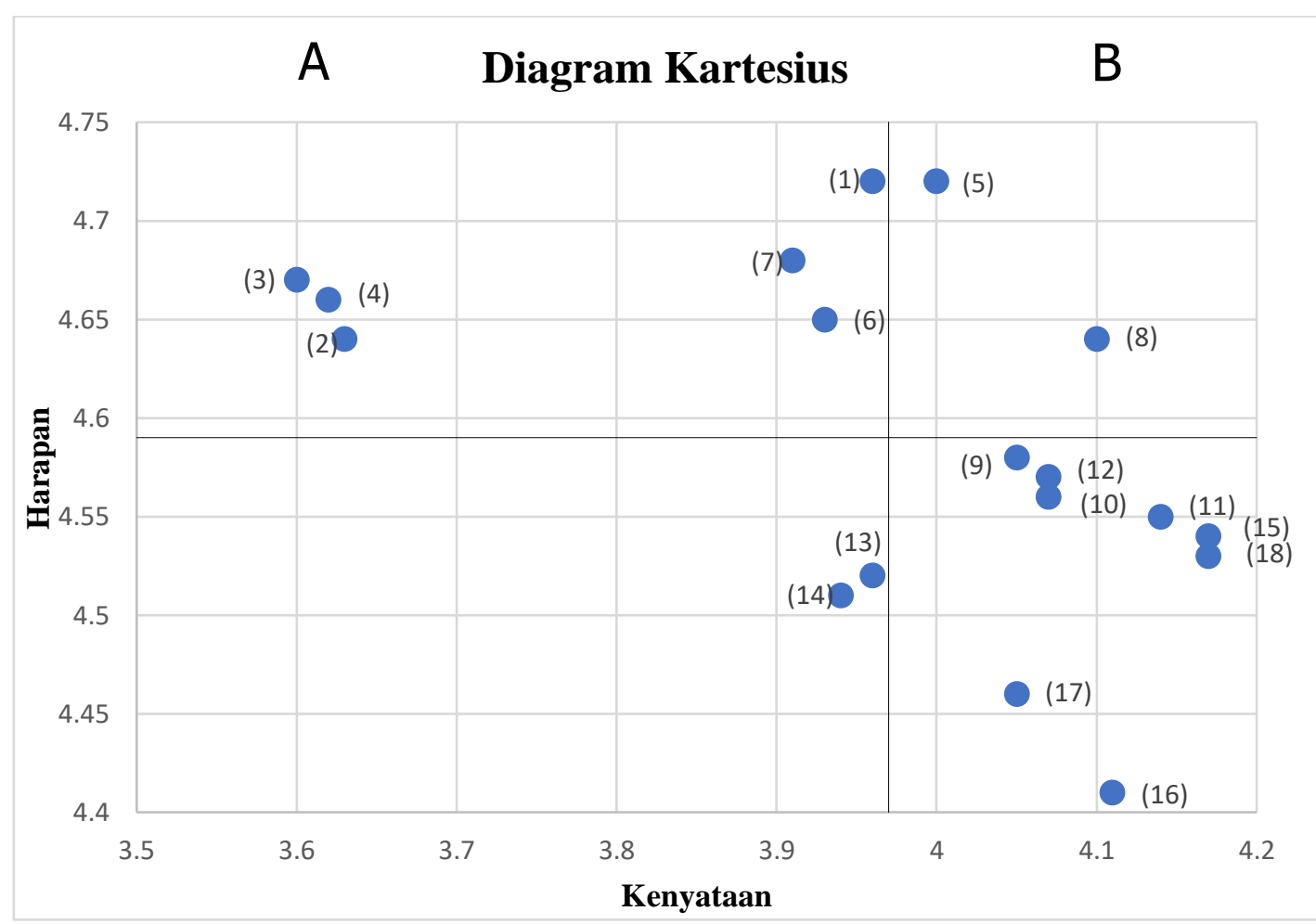


Keterangan Diagram Kartesius :

A. Kuadran A yaitu dimana tingkat harapan atau kepentingan tinggi tetapi kenyataan rendah, sehingga menjadi prioritas utama dalam perbaikan kualitas mutu pelayanan. Dalam penelitian ini, yang menjadi prioritas utama untuk perbaikan kualitas pelayanan adalah :

1. Dimensi Kehandalan 1 : Prosedur penerimaan sampel uji yang cepat dan tepat

2. Dimensi Kehandalan 2 : Pelayanan pemeriksaan (analisa) sampel uji yang cepat dan tepat

3. Dimensi Kehandalan 3 : Jadwal pelayanan pemberian hasil uji yang telah selesai sesuai dengan waktu yang telah di tentukan

4. Dimensi Kehandalan 4 : Prosedur pelayanan tidak berbelit-belit

5. Dimensi Ketanggapan 6 : Petugas memberikan informasi yang jelas dan mudah di mengerti

6. Dimensi Ketanggapan 7 : Pelayanan yangcepat pada saat pelanggan membutuhkan

B. Kuadran B yaitu dimana tingkat harapan dan tingkat kenyataan samasama tinggi atau setara, sehingga menjadi harapan Laboratorium untuk mempertahankannya. Dalam penelitian ini, yang dapat dipertahankan dalam meningkatkan kualitas pelayanan di UPTD Laboratorium Lingkungan Dinas Lingkungan Hidup Provinsi Jambi adalah :

1. Dimensi Ketanggapan 5 : Kemampuan petugas labor untuk dapat menyelesaikan hasil uji dengan cepat tanggap

2. Dimensi Keyakinan 8 : Pegetahuan dan keterampilan petugas dalam menetapkan hasil uji

\section{PEMBAHASAN}

\section{Gambaran Kepuasan Dilihat dari Dimensi Kehandalan}

Hasil penelitian menunjukkan tingkat kesesuaian antara harapan dan
C. Kuadran C

Kuadran c yaitu dimana tingkat harapan dan kenyataan sama-sama rendah sehingga belum perlu menjadi prioritas utama yang harus diperbaiki. Dalam penelitian ini, yang belum menjadi prioritas utama untuk perbaikan adalah :

1. Dimensi Empati 13 : Perhatian terhadap keperluan pelanggan

2. Dimensi Empati 14 : Pelayanan kepada setiap pelanggan tanpa memandang status sosial dan lainlain.

D. Kudran D

Kuadran D yaitu dimana tingkat harapan rendah tetapi kenyataan tinggi, sehingga dianggap berlebihan dan tidak begitu penting. Dalam penelitian ini, faktor yang dianggap berlebihan di Laboratorium adalah :

1. Dimensi Keyakinan 9 : Keterampilan petugas labor dan analis dalam bekerja

2. Dimensi Keyakinan 10 : Pelayanan yang sopan dan ramah

3. Dimensi Keyakinan 11 : Jaminan keamanan pelayanan dan kepercayaan terhadap pelayanan

4. Dimensi Empati 12 : Petugas memberikan informasi pelayanan secara cepat dan tepat kepada setiap pelanggan

5. Dimensi Berwujud 15 : Kebersihan, kerapiam dan kenyamanan ruangan

6. Dimensi Berwujud 16 : Penataan interior dan eksterior ruangan

7. Dimensi Berwujud 17 : Kelengkapan, kesiapan dan kebersihan alat-alat yang di pakai

8. Dimensi Berwujud 18 : Kerapian dan kebersihan penampilan petugas

kenyataan pada dimensi kehandalan $79,20 \%$. Jika dilihat dari atribut pada dimensi kehandalan menunjukkan bahwa atribut jadwal pelayanan pemberian hasil uji yang telah selesai sesuai dengan waktu 
yang telah ditentukan, memiliki persentase paling rendah yaitu sebesar $76,95 \%$.

Pada dimensi kehandalan, responden tidak puas terhadap pelayanan yang di berikan oleh UPTD Laboratorium Lingkungan Dinas Lingkungan Hidup Provinsi Jambi. Responden merasa bahwa pemberian hasil uji tidak sesuai dengan jadwal yang telah ditentukan. Tingkat pelayanan Laboratorium yang baik harusnya mampu memberikan pelayanan dengan segera, tepat dan memuaskan, merefleksikan konsistensi dan kehandalan. Jika pelayanan belum bisa memuaskan pelanggan hal ini akan berakhir pada rendahnya kepuasan itu sendiri. Namun pada kenyataannya pelayanan yang di berikan kurang cepat dan tepat. Pelanggan ingin hasil uji yang dikeluarkan tepat waktu, karena hasil uji tersebut akan menjadi laporan tentang kualitas lingkungan perusahaan mereka. Perlunya laporan kualitas lingkungan untuk perusahaan agar aktivitas pekerjaan perusahaan senantiasa terpantau dan lingkungan yang sehat untuk pekerja serta masyarakat sekitar.

Banyak faktor penyebab ketidakpuasan pelanggan dalam pelayanan, salah satunya yaitu mutu pelayanan. Mutu pelayanan yang baik saat ini menjadi penting untuk meningkatkan kualitas pelayanan dan kepuasan pelanggan. Sehingga pelanggan yang puas akan berbagi kepuasan dengan produsen atau penyedia jasa. Bahkan pelanggan yang puas akan berbagi rasa dan pengalaman dengan pelanggan lain. ${ }^{8}$

Untuk itu disarankan kepada UPTD Laboratorium Lingkungan Dinas Lingkungan Hidup Provinsi Jambi untuk mengoptimalisasi kebijakan SOP Laboratorium, serta merumuskan komitmen bersama bagi pegawai Laboratorium untuk melakukan pelayanan yang memuaskan.

\section{Gambaran Kepuasan Dilihat dari Dimensi Ketanggapan}

Hasil penelitian menunjukkan bahwa tingkat kesesuaian antara kenyataan pada dimensi ketanggapan sebesar $84,20 \%$. Jika dilihat dari atribut pada dimensi ketanggapan menunjukkan bahwa atribut Pelayanan yang cepat pada saat pelanggan membutuhkan memiliki nilai persentasi paling rendah yaitu $83,41 \%$.

Pada dimensi ketanggapan menunjukkan bahwa responden kurang puas terhadap pertanyaan tentang pelayanan yang cepat pada saat pelanggan membutuhkan. Hal tersebut terjadi karena petugas front liner yang ada hanyalah dua orang, saat pelanggan sedang ramai maka petugas akan sulit untuk melayani seluruh pelanggan dengan cepat. Kadang kala pelanggan yang lokasinya jauh menghubungi petugas front liner untuk bertanya tetapi tidak dijawab, maka dari itu pelayanan yang cepat pada saat pelanggan membutuhkan merupakan keluhan dari pelanggan yang mendapat pelayanan di UPTD Laboratorium Lingkungan Dinas Lingkungan Hidup Provinsi Jambi.

Daya tanggap ialah keinginan para staff untuk membantu para pelanggan dan memberikan pelayanan dengan tanggap. ${ }^{9}$ Ketanggapan merupakan dimensi kualitas pelayanan paling dinamis. Harapan pelanggan terhadap kecepatan pelayanan hampir dapat dipastikan akan berubah dengan kecenderungan naik waktu dari ke waktu. Pelayanan yang tanggap, juga sangat dipengaruhi oleh sikap front liner staff (petugas yang berhadapan langsung dengan pelanggan). Tanggapan merupakan suatu kemauan untuk membantu dan memberikan pelayanan yang cepat dan tepat kepada pelanggan melalui penyampaian informasi yang jelas. Membiarkan konsumen menunggu tanpa adanya suatu alasan yang jelas menyebabkan persepsi yang negatif dalam kualitas pelayanan. ${ }^{10}$

Untuk itu diharapkan ada tenaga bantuan bagi pegawai yang sedang tidak ada pekerjaan pada saat itu. Karena tugas fornt liner staff di Laboratorium bukan hanya melayani pelanggan, tetapi juga 
mengambil botol sampel yang akan di kembalikan kepada pelanggan, mengontrol hasil uji yang terlambat, memberikan hasil uji, dan lain-lain, akan sulit jika hanya dilakukan oleh dua orang saat pelanggan sedang ramai.

\section{Gambaran Kepuasan Dilihat dari Dimensi Keyakinan}

Hasil penelitian menujukkan bahwa tingkat kesesuian antara harapan dan kenyataan pada dimensi keyakinan adalah sebesar $89,22 \%$. Atribut yang memiliki nilai persentasi terendah adalah pengetahuan dan keterampilan petugas dalam menetapkan hasil uji yaitu sebesar $88,27 \%$.

baik oleh responden pada atirbut pengetahuan dan keterampilan petugas dalam menetapkan hasil uji. Responden mengeluhkan hasil uji yang diterima terkadang tidak sesuai dan membutuhkan revisi ulang. Hal tersebut menyebabkan keterlambatan perusahaan mengirimkan laporan kualitas lingkungan yang harus dilaporkan kepada yang berwenang. Terkadang petugas salah mengembalikan botol hasil uji sehingga botol yang seharusnya diterima tidak sesuai. Hal-hal seperti ini akan menimbulkan keraguan dari responden jika ingin melakukan pengujian di Laboratorium ini.

Keyakinan merupakan

pengetahuan, kesopan santunan dan kemampuan para pegawai perusahaan menumbuhkan rasa percaya para pelanggan kepada perusahaan, meliputi pengetahuan, kemampuan, kesopanan, dan sifat dapat dipercaya dimiliki staf, bebas dari bahaya resiko keragu-raguan. ${ }^{9}$ Dimensi keyakinan merupakan dimensi kualitas yang berhubungan dengan kemampuan perusahaan dan perilaku fornt liner staf dalam menanamkan rasa percaya dan keyakinan kepada para pelanggannya. Berdasarkan riset yang dilakukan, ada empat aspek dari dimnesi ini, yaitu keramahan, kompetisi, kredibilitas dan keamanan.
Sebaiknya petugas laboratorium lebih teliti dalam melakukan pekerjaan agar dapat meyakinkan pelanggan untuk terus melakukan pengujian sampel di UPTD Laboratorium Lingkungan Dinas Lingkungan Hidup Provinsi Jambi.

\section{Gambaran Kepuasan Dilihat dari Dimensi Empati}

Hasil penelitian menunjukkan bahwa tingkat kesesuaian anatara harapan dan kenyataan ada di dimensi empati ialah sebesar $91,07 \%$. Atribut yang memiliki persentase terendah adalah pelayanan kepada setiap pelanggan tanpa memandang status sosial dan lain-lain yaitu sebesar $87,43 \%$.

Responden merasa kurang puas pada dimensi empati karena pelanggan menganggap bahwa ada pelayanan khusus bagi pelanggan tertentu. Khususnya pada kondisi saat ini, UPTD Laboratorium Lingkungan DLH Provinsi Jambi mengambil kebijakan hanya menerima 4050 perusahaan saja yang sampelnya dapat diujikan di laboratorium tersebut. Pelanggan akan meregistrasi di hari dan jam yang sudah ditentukan oleh petugas dan menghubungi petugas tersebut dengan pesan di Whatsapp secara personal. Pelanggan yang meregistrasi 50 di awal akan diterima dan selebihnya akan ditolak. Tetapi ada beberapa pelanggan yang tidak tergistrasi dan merasa adanya pilih kasih antara petugas dan perusahaan.

Perhatian merupakan rasa peduli untuk memberikan perhatian secara individual kepada pelanggan, memahami kebutuhan pelanggan, serta kemudahan untuk dihubungi. ${ }^{11}$ Nilai pelanggan adalah ikatan emosional yang terjalin antara pelanggan dan produsen setelah pelanggan menggunakan produk dan jasa dari perusahaan dan mendapati bahwa produk atau jasa tersebut memberi nilai tambah. ${ }^{9}$

Sebaiknya UPTD Laboratorium Lingkungan Dinas Lingkungan Hidup Provinsi Jambi membuat grup pelanggan di Whatsapp yang menjadi pelanggan di laboratorium tersebut, mengingat 
pelanggan-pelanggan yang rata-rata sudah menggunakan smartphone, agar dapat memberikan informasi terkait pengujian sampel dan untuk registrasi. Sehingga registrasi terasa lebih terbuka dan dapat dilihat oleh seluruh pelanggan, untuk mengurangi prasangka tidak baik oleh pelanggan.

\section{Gambaran Kepuasan Dilihat dari Dimensi Berwujud}

Hasil penelitian menunjukkan bahwa tingkat kesesuaian antara harapan dengan kenyataan pada dimensi berwujud adalah sebesar 93,13\%. Atribut yang memiliki nilai persentase terendah kelengkapan, kesiapan dan kebersihan alat-alat yang dipakai adalah 90,80\% .

Berwujud merupakan kemampuan suatu perusahaan dalam menunjukkan eksistensinya kepada pihak eksternal. Penampilan kantor dan karyawan, kemampuan sarana dan prasarana fisik perusahaan (termasuk fasilitas komunikasi), serta lingkungan sekitarnya adalah bukti nyata pelayanan yang diberikan oleh pembeli jasa. Penampilan pelayanan tidak hanya sebatas pada penampilan fisik bangunan yang megah tetapi juga penampilan petugas dan sarana dan prasarana penunjang. ${ }^{10}$

Pada dimensi bukti fisik menujukkan bahwa responden kurang puas pada pertanyaan penataan interior dan eksterior ruangan. Responden mengatakan penataan ruangan yang kurang sesuai, karena kursi tunggu yang bersebelahan dengan rak dorong sampel uji yang diantar oleh pelanggan. Terkadang aroma sampel uji tercium sangat menyengat dan kurang enak. Tidak adanya poster yang menunjukan edukasi kepada pelanggan seperti jadwal waktu pengujian sampel atau persyaratan sampel uji yang sesuai SNI.

Pada dimensi bukti fisik menujukkan bahwa responden kurang puas pada kelengkapan, kesiapan dan kebersihan alat-alat yang dipakai. Responden mengatakan tidak disedikannya saran cuci tangan di dekat tempat penerimaan sampel. Setalah melakukan serah terima sampel, baik petugas maupun pelanggan tidak mencuci tangan terlebih dahulu, tetapi langsung menjalankan urusan administrasi terkait sampel yang diterima. Setelah meletakkan sampel, petugas dan pelanggan terkadang menggunakan alat tulis yang sama tanpa mencuci tanganterlebih dahulu.

Sebaiknya disediakan tempat mencuci tangan di area sekitar tempat peletakkan sampel, agar petugas penerima sampel dan pelanggan dapat segara mencuci tangan setelah memegang botol sampel.

\section{Prioritas Peningkatan Kualitas Pelayanan Berdasarkan Analisis Diagram Kartesisus}

Hasil penelitian menunjukkan bahwa berdasarkan diagram kartesius yang menjadi prioritas utama untuk perbaikan kualitas pelayanan ada pada kuadran A yaitu :

1. Dimensi Kehandalan 1 : Prosedur penerimaan sampel uji yang cepat dan tepat

2. Dimensi Kehandalan 2 : Pelayanan pemeriksaan(analisa) sampel uji yang cepat dan tepat

3. Dimensi Kehandalan 3 : Jadwal pelayanan pemberian hasil uji yang telah selesai sesuai dengan waktu yang telah di tentukan

4. Dimensi Kehandalan 4 : Prosedur pelayanan tidak berbelit-belit

5. Dimensi Ketanggapan 6 : Petugas memberikan informasi yang jelas dan mudah di mengerti

Perusahaan dapat mengetahui peringkat pelayanan menurut kepuasan pelanggan dan kinerja perusahaan serta mengidentifikasikan tindakan apa yang perlu dilakukan manajemen perusahaan melalui penjabaran keseluruhan atribut kualitas pelayanan kedalam diagram kartesius. $^{8}$

Kuadran A adalah lokasi berbagai aspek atau atribut layanan yang dirasakan 
penting oleh pelanggan, tetapi pelakasanaannya menurut pelanggan masih kurang. Dengan demikian, atribut layanan jasa tersebut harus menjadi perhatian utama di dalam peningkatan mutu atau kinerja. ${ }^{11}$

Kuadran A merupakan kualitas atau kinerja pelayanan jasa yang dianggap pelanggan masih dibawah harapan, sehingga berdampak pada ketidakpuasan pelanggan pada atribut yang terdapat pada kuadran tersebut. Untuk itu perlu dilakukan berbagai upaya untuk meningkatkan kualitas pelayanan sebagai berikut:

a. Dimensi Kehandalan pertanyaan 1,2,3 dan 4 : Penyempurnaan kebijakan SOP Pelayanan Laboratorium Lingkungan yang mencakup pemeriksaan kualitas air, udara dan tanah disesuaikan dengan peta proses bisnis berdasarkan Permen PAN RB nomor 19 tahun 2018, sehingga alur pelayanan dan petugas penanggung jawab menjadi jelas dan merumuskan komitmen bersama bagi pegawai Laboratorium untuk melakukan pelayanan yang memuaskan.

b. Dimensi Ketanggapan pertanyaan 6 dan 7 : Mengatur dan membuat jadwal untuk pelayanan di front liner staff dan memberdayakan pegawai bagian lapangan yang sedang tidak turun lapangan untuk membantu front liner staff pada saat pelanggan sedang ramai.

\section{KESIMPULAN DAN SARAN}

Berdasarkan hasil penelitian dan pembahasan maka dapat ditarik kesimpulan : Prioritas utama untuk diperbaiki dalam memberikan pelayanan jasa terhadap pelanggan adalah Prosedur penerimaan sampel uji yang cepat dan tepat, Pelayanan pemeriksaan (analisa) sampel uji yang cepat dan tepat, Jadwal pelayanan pemberian hasil uji yang telah selesai sesuai dengan waktu yang telah di tentukan, Prosedur pelayanan tidak berbelit-belit, Petugas memberikan informasi yang jelas dan mudah di mengerti dan Pelayanan yang cepat pada saat pelanggan membutuhkan. Demi menjaga kepercayaan pelanggan akan pelayanan di UPTD Laboratorium Lingkungan Dinas Lingkungan Hidup Provinsi Jambi yang berkualitas, sudah selayaknya pihak di UPTD Laboratorium Lingkungan Dinas Lingkungan Hidup Provinsi Jambi memperhatikan penilaian pasien yang menjadi responden dalam penelitian ini. Kemudian juga disarankan kepada petugas UPTD Laboratorium Lingkungan Dinas Lingkungan Hidup Provinsi Jambi agar meningkatkan kualitas pelayanan melalui berbagai upaya yaitu :

a. Penyempurnaan kebijakan SOP UPTD Laboratorium Lingkungan Dinas Lingkungan Hidup Provinsi Jambi dan merumuskan komitmen bersama bagi pegawai untuk melakukan pelayanan yang memuaskan.

b. Memberikan on the job/training kepada petugas agar lebih ramah, peduli dan mampu memberikan pelayanan prima.

\section{DAFTAR PUSTAKA}

1. Kemenkes RI (2009). Pelayanan Publik tentang Kesehatan RI. Jakarta

2. KemenLHK RI (2014). Pusat Standarisasi Lingkungan dan Kehutanan. Jakarta

3. Supranto. (2011). Pengkuran Tingkat Kepuasan Pelanggan. Jakarta : Rineka Cipta

4. Ndambuku, J (2013). The Level of Patiens Satisfation anda Perception On Quality of Nursing Service In the Renal Unit, Kenyatta National Hospital Nairobi, Kenya. Journal Medicine and Health Care Vol:3, No:2.

5. Arikunto. 2010. Prosedur Penelitian Suatu Pendekatan Praktis. Jakarta : Rineka Cipta

6. Witter et al, (2015). Patient's Perception of Health Care Quality Satisfaction and Behavioral Intentiom : An Empirical Study In Bahrain. Internation Journal of Bussiness and Social Science 2015 ; Vol ; 3 
7. Handayani Hasibuan, (2016). Pengaruh Kualitas pelayanan, harga dan lokasi terhadap Kepuasan pengguna jasa damri di bandara Soekarno-Hatta (studi kasus terhadap pengguna jasa Damri bandara Soekarno-Hatta. Universitas Islam Negeri Syarif Hidayatullah Jakarta.

8. Yamit, Z. (2011). Manejemen Kualitas Priduk dan Jasa. Yogyakarta : Ekonisia

9. Tjiptono. (2016). Service Quality dan Satisfaction (4 ed). Yogakarta: Andi Offset

10. Lupiyoadi. (2011). Manajemen Pemasaran Edisi Kedua. Jakarta : Salemba Empat

11. Pohan, Imbalo (2006). Jaminan Mutu Layanan Kesehatan, Dasar-Dasar Pengertian dan Penerapan. Jakarta : EGC

12. Umam, Chairul, et al (2019). Analisis Kepuasan Pasien terhadap Mutu Pelayanan KesehatanRawat jalan dengan Metode IPA (Importance Performance Analysis) di Puskesmas Bogor Tengah Kota Bogor Tahun 2018. Promotor : Jurnal Mahasiswa Kesehatan Masyarakat Vol 2(1)7-19 